\title{
https://doi.org/10.46813/2021-131-074 \\ INVESTIGATION OF OZONE SYNTHESIS IN THE NEGATIVE PULSED CORONA DISCHARGE IN OXYGEN AT THE COMBINED SUPPLY VOLTAGE
}

\author{
V.I. Golota, B.B. Kadolin, I.A. Paschenko \\ IPENMA NSC “Kharkov Institute of Physics and Technology”, Kharkiv, Ukraine \\ E-mail: paschenko@kipt.kharkov.ua
}

The influence of combined supply voltage parameters (bias voltage and voltage pulse amplitude) on efficiency of ozone synthesis in the negative pulsed corona discharge in oxygen was obtained. Pulse overvoltage led to intensification of discharge processes. Bias voltage applied during the discharge channel relaxation essentially increased the efficiency of ozone synthesis. It was established that the "optimal" bias voltage which provides maximum ozone generation doesn't depend on voltage pulse amplitude, but depends on input oxygen concentration and generated ozone concentration.

PACS: 52.75.-d, 52.77.-j, 52.80.Hc, 82.33.Xj

\section{INTRODUCTION}

As a result of increased industrial use of ozone, the economic and operational requirements for the processes of its generation have been raised. Along with the traditional barrier ozone generators, more and more attention is paid to the barrierless discharges in a point-toplane electrode system [1]. One of the advantages of the barrierless discharge over the barrier discharge is the ability to control discharge processes using a combined supply voltage. Due to the combined power supply, high voltage can be applied to the interelectrode gap during the discharge breakdown and can be completely or partially removed during the channel relaxation. The matter is that negative corona discharge at the DC voltage implemented as Trichel pulses. Plasma-chemical processes take place during these current pulses and between the pulses only the charge particles motion occurs [2].

As was shown earlier [3], the pulsed power supply results in a significant increase in both the maximum achievable ozone concentration and the efficiency of its synthesis. As it was assumed, the pulse power supply provides overvoltage on the discharge gap during its breakdown that leads to intensification of ionization and excitation processes. Voltage decrease between pulses gives the decrease of energy losses for charge particles movement during the relaxation of the current channel.

At subsequent studies it was shown that the discharge-to-spark transition voltage depended on the bias voltage [4]. In sum, a hypothesis was put forward that the negative space charge initiating a spark breakdown is accumulated in the interelectrode gap. The use of low-voltage DC component between high-voltage pulses contributes to a faster absorption of the charge and expansion of the operating voltage range for the ozone generator.

So, the ability to apply higher voltage at the moment of discharge breakdown results in the increased specific energy input into the discharge. On the other hand, the low-voltage DC component of the combined power supply unit ensures the directional ion motion (electrons left the gap or "stuck") in the decaying current channel, and the energy is spent on the processes not directly related to the ozone synthesis. In this paper, the results of the study for the dependence of ozone synthesis efficiency on the low-voltage DC component of the combined power supply in oxygen $(90 . . .96 \%)$ are presented.

\section{EXPERIMENTAL UNIT}

The plasma-chemical reactor (PCR) was a cylindrical coaxial system. The PCR anode was made of finely dispersed graphite $500 \mathrm{~mm}$ long and $38 \mathrm{~mm}$ in inner diameter. A sectioned cathode was located along the axis of the reactor, which consisted of 54 "star-like" electrode sections separated by cylindrical spacer sleeves $8 \mathrm{~mm}$ long. Each star-like cathode section was a $0.3 \mathrm{~mm}$ thick stainless steel disc with 15 radially spaced beams. Each beam was $4 \mathrm{~mm}$ high, $0.6 \mathrm{~mm}$ wide and had a wedge-like apex with a $30^{\circ}$ angle. The permissible deviation for the axis of the sectioned cathode from the axis of the cylindrical anode was no more than $50 \mu \mathrm{m}$. The electrical capacitance of one PCR was $44.5 \mathrm{pF}$. The experiments were carried out using the module consisting of one to four PCR connected in series along the gas path and in parallel to the electric power supply unit.

In addition to PCR, the experimental stand (Fig. 1) included an "oxygen source" module. This module provided stable supply of the oxygen-air mixture with oxygen concentration of up to $96 \%$ and flow rate of up to $16 \mathrm{l} / \mathrm{min}$.

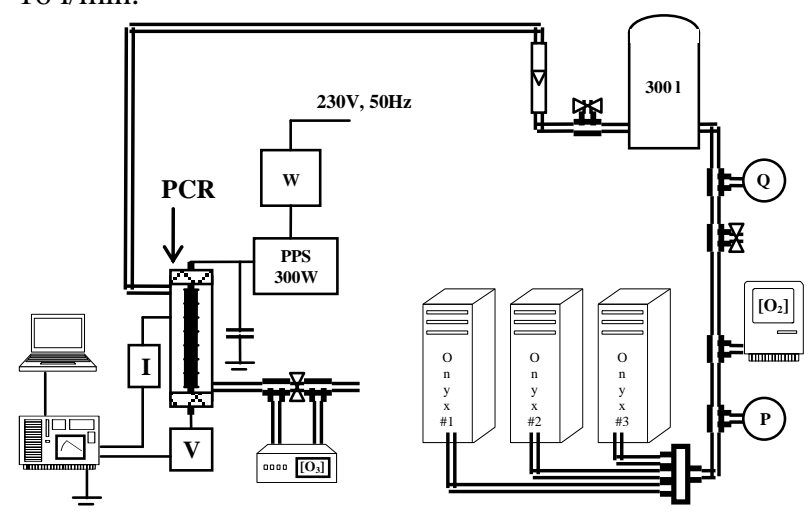

Fig. 1. Scheme of the experimental stand for studying the PCR operation on oxygen 
This module contained three Onyx $^{+}$oxygen concentrators connected in parallel to the gas path, manometer, oxygen meter $\mathrm{O}_{2}$-Analyzer $(0 \ldots 100 \%)$, flow meter EPI $8636 \mathrm{MP} \quad(0 \ldots .25 \mathrm{nl} / \mathrm{min})$, receiver (300 1), flow meters PM-0.63Г and PM-4Г.

The second module of the stand included the test PCR(s), pulse power supply unit (PPS) and diagnostic tools. The high-voltage PPS made it possible to generate high-voltage pulses of submicrosecond duration $(800 \ldots 2200 \mathrm{~ns})$ with the repetition rate of $1 . .20 \mathrm{kHz}$ and the amplitude of up to $12 \mathrm{kV}$. The rise time of the pulse leading edge was $\approx 500 \mathrm{~ns}$. The typical oscillogram of the high-voltage pulse for the equivalent load with the capacity of $44 \mathrm{pF}$ is shown in Fig. 2.

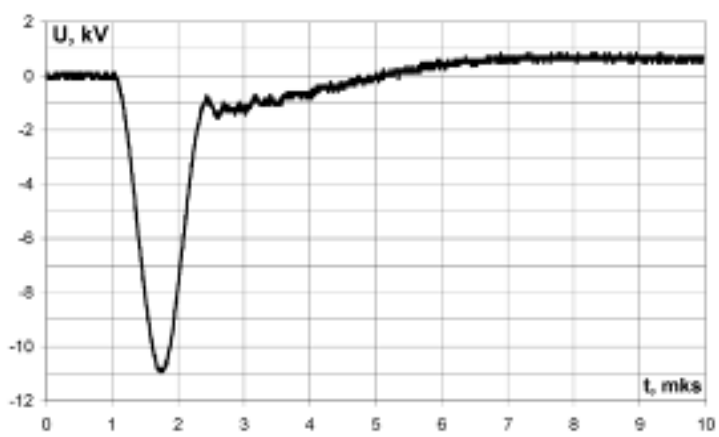

Fig. 2. The typical oscillogram of the high voltage pulse

The bias circuit was formed by the high-voltage capacitor $\mathrm{C}$ and the group of high-voltage diodes $\mathrm{D}$ (Fig. 3). The bias voltage of negative polarity $\boldsymbol{U}_{\boldsymbol{d}}$ was maintained by this circuit in the discharge gap in the interval between the high-voltage pulses.

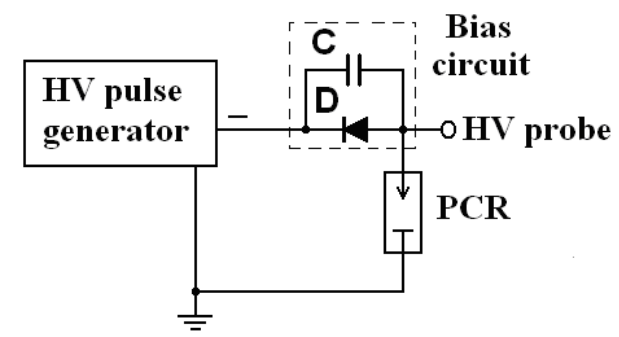

Fig. 3. Electric circuit for connecting the PCR unit with the "bias chain"

The voltage across the discharge gap was measured via the digital oscilloscope Tektronix TDS-2024V with the transmission frequency of $200 \mathrm{MHz}$ using the highvoltage probe $\mathrm{P} 6015 \mathrm{~A}$ with the division ratio of 1:1000 and the bandwidth of $10 \mathrm{~Hz} . .75 \mathrm{MHz}$. The signal from the oscilloscope was sent to the computer. The power consumed by PPS was recorded with a wattmeter. The ozone concentration at the PCR output was measured with the ozone meter Teledyne M465H.

\section{EXPERIMENTAL RESULTS}

The effect of the bias voltage $\boldsymbol{U}_{\boldsymbol{d}}$ on the ozone synthesis in PCR was investigated. Voltage $\boldsymbol{U}_{\boldsymbol{d}}$ could varied by changing the capacitance of the bias circuit. The experiments were carried out for various amplitude values of the high-voltage pulse $\boldsymbol{U}_{\boldsymbol{m}}$. It should be noted that dependence of ozone concentration at the output of the PCR unit on the bias voltage (Fig. 4) had a maximum point. So, the corresponding value of bias voltage is the "optimal" for ozone synthesis under current conditions of gas supply.

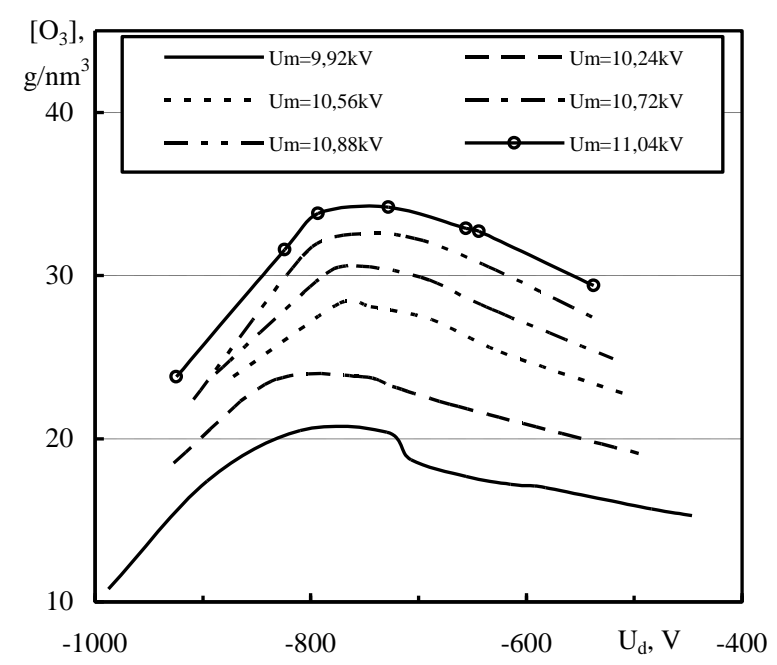

Fig. 4. Dependence of ozone concentration $\left[\mathrm{O}_{3}\right]$ at the output of the PCR unit on the bias voltage $\boldsymbol{U}_{d}$ at different amplitudes of the voltage pulse $\boldsymbol{U}_{\boldsymbol{m}}$. Oxygen concentration is $91.3 . . .91 .6 \%$, flow rate is $2.5 \mathrm{l} / \mathrm{min}$

At the optimal (from the point of view of the maximum ozone concentration synthesis) values of bias voltage, the power consumption also increase (Fig. 5).

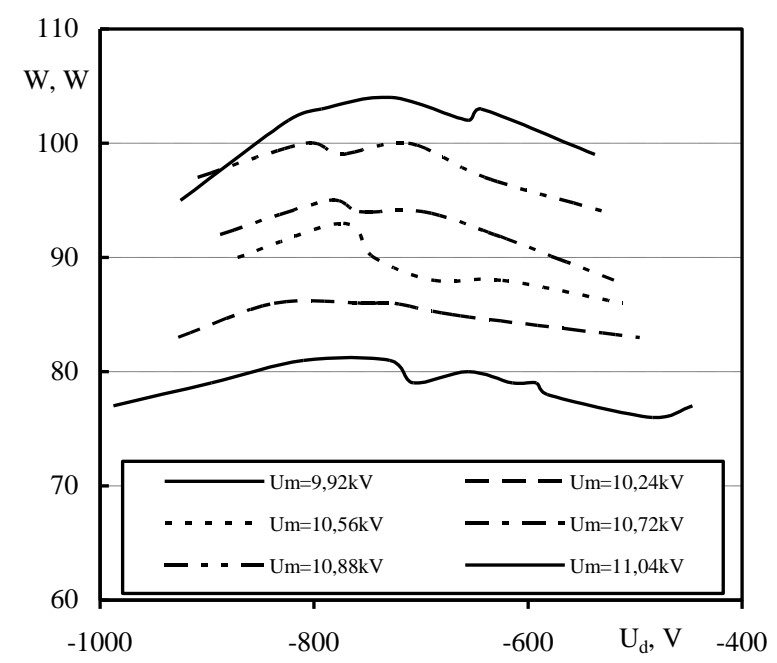

Fig. 5. Dependence of the power $\boldsymbol{W}$ consumed by the power supply unit on the bias voltage $\boldsymbol{U}_{\boldsymbol{d}}$ at different amplitudes of the voltage pulse $\boldsymbol{U}_{\boldsymbol{m}}$. Oxygen concentration is $91.3 . .91 .6 \%$, flow rate is $2.5 \mathrm{l} / \mathrm{min}$

However, at the optimal choice of bias voltage, the increase in ozone concentration occurred not only due to the increase in power consumption. In Fig. 6 the dependence of energy consumption for ozone synthesis $\left(\mathbf{k},(\mathrm{W} \cdot \mathrm{h}) / \mathrm{gO}_{3}\right)$ on the bias voltage $\boldsymbol{U}_{\boldsymbol{d}}$ is presented. For clarity, the value of power consumption was reduced by the power constantly consumed by the power supply source (fan power and stabilizer power). It was $38 \mathrm{~W}$ for the power supply unit being used. 


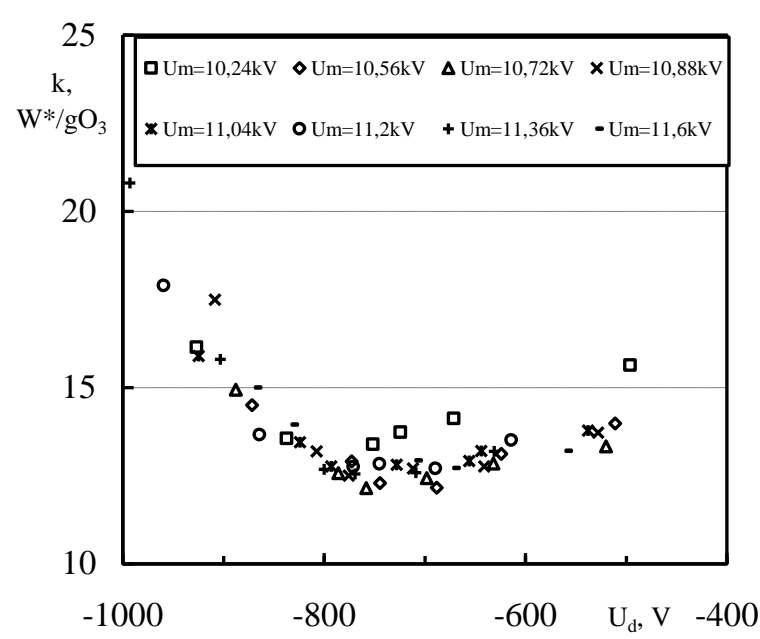

Fig. 6. Dependence of energy consumption for the ozone synthesis $\boldsymbol{k}$ on the bias voltage $\boldsymbol{U}_{\boldsymbol{d}}$ at different amplitudes of the voltage pulse $\boldsymbol{U}_{\boldsymbol{m}}$. Oxygen concentration is $91.3 . .91 .6 \%$, flow rate is $2.5 \mathrm{l} / \mathrm{min}$

In addition, it can be seen (see Fig. 6) that the dependence of energy consumption for ozone synthesis on bias voltage is almost independent of the highvoltage pulse amplitude.

Pure energy consumption of the discharge processes is of interest. The "net" power consumed by the discharge was estimated as the difference between the power consumed by the power supply unit loaded onto the PCR unit and the power consumed by the power supply source loaded onto the equivalent capacitive load. The "net" energy consumption for ozone synthesis $\boldsymbol{k}_{\boldsymbol{d}}$, taking into account only the power of discharge processes, depending on the "optimal" generated ozone concentration, is shown in Fig. 7. It should be noted that specific energy consumption for ozone synthesis is increased with increasing of generated ozone concentration.

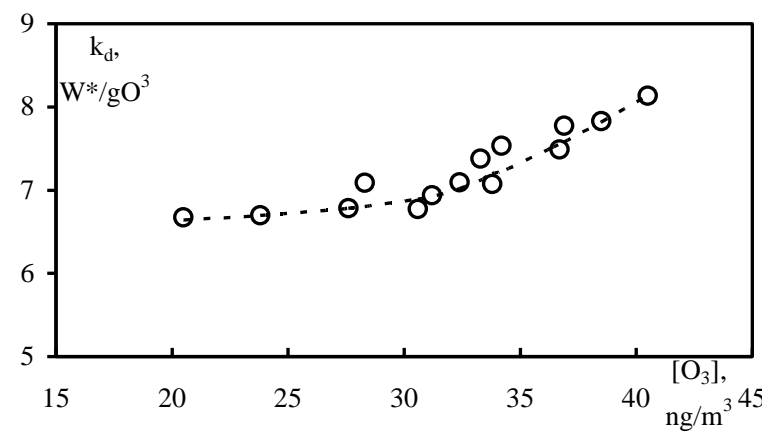

Fig. 7. Dependence of "net" energy consumption for the ozone synthesis $\boldsymbol{k}_{\boldsymbol{d}}$ on the value of the "optimal" generated ozone concentration. Oxygen concentration is $91.3 . .91 .6 \%$, flow rate is $2.5 \mathrm{l} / \mathrm{min}$

The data on the experiments with different oxygen concentrations $(90 . .96 \%)$ in the feed gas and different gas flow rates $(0.25 \ldots 2.51 / \mathrm{min})$ are presented in Fig. 8 . Experimental data for $96 \%$ oxygen concentration show that optimal choice of bias voltage can increase output ozone concentration even into two times. Besides, one can see that the "optimal" bias voltage have to be raised in the case of reduction of flow rate (increasing of generated ozone concentration) and in the case of decreasing of input oxygen concentration.

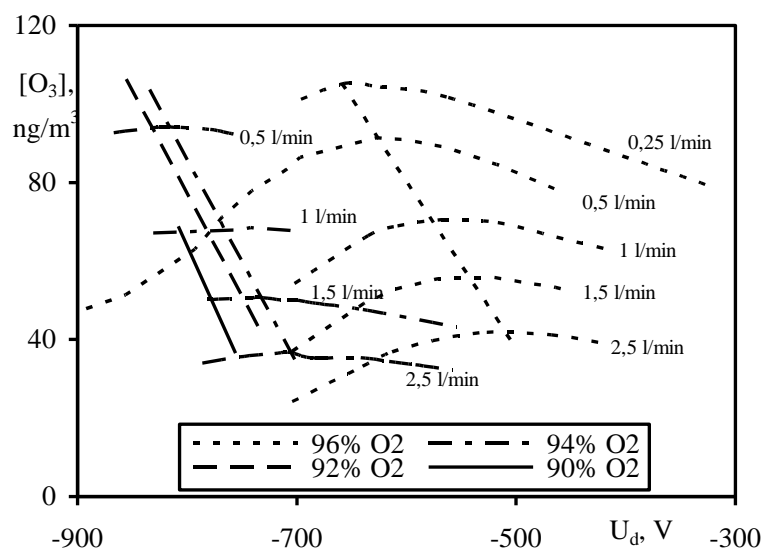

Fig. 8. Dependence of the ozone concentration $\left[\mathrm{O}_{3}\right]$ at the output of the PCR unit on the bias voltage $\boldsymbol{U}_{\boldsymbol{d}}$ at different oxygen concentrations and flow rates. $\boldsymbol{U}_{\boldsymbol{m}}=11.2 \mathrm{kV}$

\section{CONCLUSIONS}

The use of bias voltage has a significant effect on efficiency of ozone generation in the negative pulsed corona discharge. The correct choice of the "optimal" bias voltage $\boldsymbol{U}_{\boldsymbol{d}}$ results in maximum of consumed power and minimum of specific energy consumption for ozone synthesis that led to the maximum ozone output. The wrong one can decrease this output at dozen of percents.

We have an experimental fact that there is no dependence (weak dependence) of the "optimal" bias voltage on the voltage pulse amplitude.

It was found that the value of the optimal bias voltage should be decreased with decreasing of expected ozone output (increasing of flow rate), and also it should be increased with decreasing of input oxygen concentration.

\section{REFERENCES}

1. Yu.V. Filippov, V.A. Voblikova, and V.I. Panteleev, Electrosynthesis of Ozone. Moscow, 1987.

2. Yu.P. Raizer. Gas discharge physics. Springer: "Verlag", 1991.

3. V.I. Golota, L.M. Zavada, O.V. Kotyukov, O.V. Poliakov, S.G. Pugach. Ozone synthesis efficiency upgrading in the pulsed point-to-plane gas discharge // Problems of Atomic Science and Technology. Series «Plasma Physics and New Methods Acceleration». 2006, № 5, p. 91-94.

4. S.M. Mankovskyi, B.B. Kadolin, L.M. Zavada, V.I. Golota, M.O. Yegorov. Features of the microsecond pulsed discharge ignition in oxygen in a point-to-plane configuration // Problems of Atomic Science and Technology. Series «Plasma Physics and New Methods Acceleration». 2018, №4, p. 168-171.

Article received 16.11.2020 


\section{ИССЛЕДОВАНИЕ СИНТЕЗА ОЗОНА В ОТРИЦАТЕЛЬНОЙ ИМПУЛЬСНОЙ КОРОНЕ В КИСЛОРОДЕ ПРИ КОМБИНИРОВАННОМ ПИТАНИИ}

\section{В.И. Голота, Б.Б. Кадолин, И.А. Паценко}

Обнаружено влияние параметров комбинированного питания (напряжения смещения и амплитуды импульса) на эффективность синтеза озона в отрицательной импульсной короне в кислороде. Перенапряжение во время импульса питания приводило к усилению разрядных процессов. Напряжение смещения, приложенное во время релаксации разрядного канала, существенно увеличивало эффективность синтеза озона. Имеет место «оптимальное» напряжение смещения, обеспечивающее максимальный выход озона, которое не зависит от амплитуды импульса напряжения, но зависит от концентрации кислорода и генерируемой концентрации озона.

\section{ДОСЛІДЖЕННЯ СИНТЕЗУ ОЗОНУ У ВІД'ЄМНІЙ ІМПУЛЬСНІЙ КОРОНІ В КИСНІ ПРИ КОМБІНОВАНОМУ ЖИВЛЕННІ}

\section{В.І. Голота, Б.Б. Кадолін, І.А. Пащенко}

Виявлено вплив параметрів комбінованого живлення (напруги зміщення і амплітуди імпульсу) на ефективність синтезу озону у від'ємній імпульсній короні в кисні. Перенапруга під час імпульсу живлення вела до інтенсифікації розрядних процесів. Напруга зміщення, прикладена під час релаксації розрядного каналу, значно підвищувала ефективність синтезу озону. Має місце «оптимальна» напруга зміщення, яка забезпечує максимальний вихід озону і не залежить від амплітуди імпульсу напруги, але залежить від концентрації кисню та генерованої концентрації озону. 